\title{
Serum Somatomedin C, Bioassayable Growth- Promoting Activity (Thymidine Activity), and Transferrin in Human Fetuses: In Utero Study
}

\author{
G. THIERIOT-PREVOST, F. DAFFOS, F. FORESTIER, AND J. C. JOB \\ Laboratoire de Recherches sur la Croissance, INSERM U 188 Paris, France [GTP, JCJ], Département de \\ Diagnostic Prénatal et de Foetologie, Hôpital N.D. de Bon Secours, Paris, France [FD, FF]
}

\begin{abstract}
Serum somatomedin C, thymidine uptake stimulating activity, and transferrin were measured in fetal blood collected by ultrasound-guided puncture of umbilical vessels in utero during prenatal assessment for mother-tofetus transmissible infections. Serum somatomedin $C$ and transferrin were measured by immunoassay. Thymidine activity was measured by assay of $\left[{ }^{3} \mathrm{H}\right]$ thymidine incorporation into lectin-activated human lymphocytes. Studies were conducted in 48 healthy fetuses at gestational ages 21-28 wk. From 21-24 to 25-28 wk, serum somatomedin $C$ significantly increased from $0.05 \pm 0.06$ to $0.24 \pm 0.03$ $\mathrm{U} / \mathrm{ml}$, while thymidine activity significantly decreased from $1.41 \pm 0.15$ to $0.95 \pm 0.06 \mathrm{U} / \mathrm{ml}$. Transferrin levels did not change. These data suggest that the humoral control of fetal growth at midpregnancy involves mechanisms other than direct regulation by somatomedin. (Pediatr Res 20: 71-73, 1986)
\end{abstract}

\section{Abbreviations}

Sm C, serum somatomedin

TA, thymidine activity

IGF, insulin-like growth factor

The role of growth factors in fetal development is not clear. Available information indicates that the levels of somatomedin/ IGF I and II in human fetal blood are low (1-3) while it has been reported that another factor measured as fetal brain radioreceptor assayable somatomedin is in high quantity (4). In previous studies we characterized a method to measure the growth-promoting activity of human serum by assessing the incorporation of tritiated thymidine into lectin-activated human lymphocytes $(5,6)$ and applied it to newborns $(7)$. The availability of normal fetal blood collected in utero for purpose of prenatal diagnosis of infection provided the opportunity to extend the study to fetuses. Herein we report our results in fetal blood, in association with measurement of $\mathrm{Sm} \mathrm{C}$ and transferrin.

\section{MATERIALS AND METHODS}

The serum samples used in this study were obtained by direct puncture of the umbilical vessels in utero. Intrauterine cord blood sampling was performed to determine whether maternal rubella or toxoplasmic infection had involved the fetus. The ultrasoundguided technique and its results in the prenatal diagnosis of

Received July 5, 1985; accepted August 23, 1985

Correspondence may be addressed to G. Thieriot-Prevost, Laboratoire INSERM

U 188, 74 Avenue Denfert Rochereau, 75014 Paris, France.

Supported by a grant from the Nordisk Foundation. mother to fetus transmissible infections have been published elsewhere by Daffos et al. $(8,9)$. Two $\mathrm{ml}$ of fetal blood were collected. The size of the red blood cells was determined immediately in a Coulter counter to ensure that no maternal blood was mixed with the fetal blood. After clotting at room temperature, an aliquot of serum was kept frozen at $-20^{\circ} \mathrm{C}$ for later study. For this work we used only sera from noncontaminated fetuses. Follow-up showed that they were normal at birth. We were thus able to collect samples from 48 fetuses at $21-28$ wk of pregnancy. The fetal age was assessed from both the first day of the last menses and from ultrasound measurement of cranial biparietal diameter.

Serum growth-promoting activity was measured by assessing TA into human lectin-activated lymphocytes, as detailed in several previous publications from this laboratory $(5,6,10,11)$. Each serum was studied in triplicate at six dilutions, $0.03-1.25 \%$. The value of TA was determined by reference to a standard considered to be $1 \mathrm{U} / \mathrm{ml}$, made of a pool of sera from eight normal adult males. Burn's slope ratio assay was used for this calculation. Finney's "g" test was used to compare the results. The coefficient of variation within assays was $5-10 \%$. The interassay variation was $10-15 \%$.

$\mathrm{Sm} \mathrm{C}$ was measured by radioimmunoassay using the currently available kit from Immuno Nuclear Corporation (Stillwater, MN) after separation of somatomedin from carrier protein on a Sep-Pack column. As standard we used the same pool of sera which was used in the TA assay, assuming a value of $1 \mathrm{U} / \mathrm{ml}$. The sensitivity is $0.05 \mathrm{U} / \mathrm{ml}$. The intraassay and interassay variations are less than $5 \%$. Transferrin was measured using the Mancini's technique of radial immunodiffusion (12) with NORPartigen plates (Behring, Germany). Statistical comparison of mean values were done using the Student's $t$ test.

This work was approved by the local ethics committee. Puncture of umbilical cord was performed for diagnostic purposes after informed consent from the mother. The amount of serum used for the present investigation was less than $0.5 \mathrm{ml}$ for each individual fetus.

\section{RESULTS}

The mean \pm SEM levels of TA, Sm C, and transferrin are given in Table 1. Values at 21-24 wk of pregnancy are compared to those found at 25-28 weeks. We observed a significant decrease of TA with gestational age $(p<0.001)$ which contrasted with a significant increase of Sm C $(p<0.001)$. Fetal serum transferrin levels did not change significantly with gestational age.

The individual results of $\mathrm{TA}$ and $\mathrm{Sm} \mathrm{C}$ measurements are shown in Figure 1. A negative correlation exists between TA and gestational age: $\mathrm{y}=4.24-0.125 \mathrm{x}, r=-0.76, p<0.01$. It contrasts with the positive correlation found between $\mathrm{Sm} \mathrm{C}$ and 
Table 1. Mean \pm SEM values of bioassayable TA, radioimmunoassayable $S M C$ and transferrin in fetuses aged 2l-24 and 25-28wk

\begin{tabular}{|c|c|c|}
\hline Measurements & $21-24$ wk & $25-28 w k$ \\
\hline \multirow[t]{2}{*}{$\mathrm{TA}(\mathrm{U} / \mathrm{ml})$} & $1.41 \pm 0.15$ & $0.95 \pm 0.06$ \\
\hline & $(n=24)$ & $p<0.001$ \\
\hline \multirow[t]{2}{*}{$\mathrm{Sm} \mathrm{C}(\mathrm{U} / \mathrm{ml})$} & $0.05 \pm 0.06$ & $0.24 \pm 0.03$ \\
\hline & $(n=12)$ & $p<0.001$ \\
\hline \multirow[t]{2}{*}{ Transferrin (g/liter) } & $1.09 \pm 0.05$ & $1.00 \pm 0.06$ \\
\hline & $(n=24)$ & $(n=24)$ \\
\hline
\end{tabular}
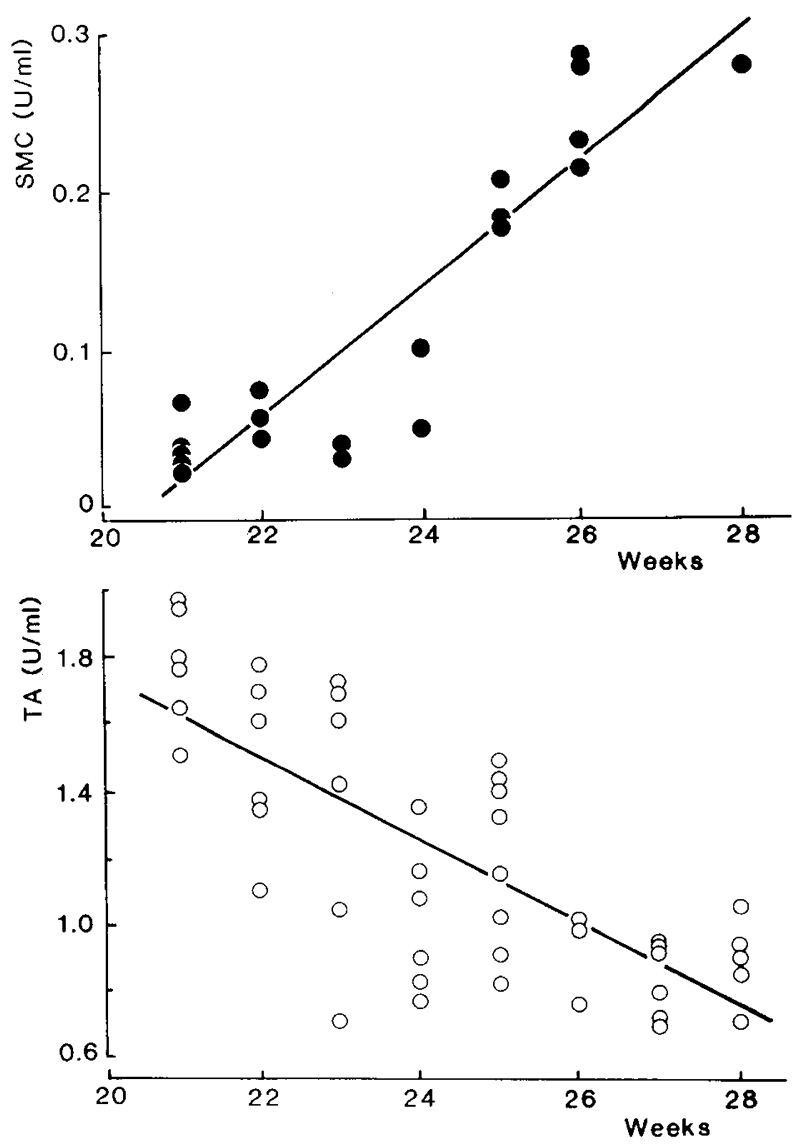

Fig. 1. Correlation between gestational age and 1) SMC $\bullet$, 2) TA $O$ in fetuses aged 21-28 wk.

the length of gestation: $\mathrm{y}=0.04 \times-0.82, r=0.91, p<0.001$. The small amount of fetal serum available was not sufficient to measure both TA and $\mathrm{Sm} \mathrm{C}$ in the same sample so that it was not possible to search for correlation between the two measurements in individual fetuses.

\section{DISCUSSION}

Few data are available regarding somatomedin and related growth factors in fetal blood. Most have been obtained by animal studies. D'Ercole et al. (1) found that Sm C in fetal pig serum, measured by radioreceptor assay using placental membranes, is about $25 \%$ of the adult level and is constant throughout fetal life. These authors first suggested that the low fetal levels of Sm $\mathrm{C}$ may reflect low levels of the serum $\mathrm{Sm}$-binding protein rather than an absolute deficiency of biologically active somatomedin. In the fetal rat, Daughaday et al. (13) demonstrated that, after preliminary acid-ethanol extraction allowing separation from carrier proteins, radioimmunoassayable IGF I is relatively ele- vated during the last days of gestation, then falls after birth, while radioreceptor assayable IGF II and multiplication-stimulating activity reach high levels in the late fetal and early postnatal days. These authors suggest that IGF II may have important growthpromoting significance in rat fetal and neonatal life.

In human fetuses it was shown that circulating $\mathrm{Sm} \mathrm{C}$ exists predominantly in a low molecular weight form of 40,000 daltons instead of the 150,000 dalton form characteristic of adult serum (2) and that specific $\mathrm{Sm} \mathrm{C}$ receptors of the placental membranes, identified from as early as $6 \mathrm{wk}$ of gestation, demonstrated no apparent structural changes through the course of pregnancy (14).

An important point is that $\mathrm{Sm} \mathrm{C}$ may be synthesized by multiple tissues. It was reported with cultured human fibroblasts (15) and demonstrated also in fetal mice (16). Recent data (17) have pointed out that the rate of DNA synthesis in cultured human fibroblasts and porcine smooth muscle cells in vitro is directly linked to their capacity to produce somatomedin-like peptides, further supporting that these peptides are involved in autocrine and paracrine growth regulation (18).

Other data in human fetuses were reported by Sara et al. (4), having collected cord blood of seven normal fetuses during fetoscopy performed between 16 and 22 wk of gestation for possible risk of congenital disease. Radioimmunoassayable somatomedin A was below detectable levels in six of seven fetuses, contrasting with high levels of what these authors named fetal brain radioreceptor-assayable $\mathrm{Sm}$. The latter was measured by a radioreceptor assay using plasma membranes of human fetal brain as receptor; levels were approximately 4-fold higher in the fetuses studied than in cord blood of term newborns or in adult serum. The authors suggested that fetal blood contains a growth factor (5) not recognized by the radioimmunoassay of Sm; they referred to this growth factor(s) as "human embryonic somatomedin." However, these data have been revised by study of interactions of human cord serum with Sm receptors of placental membranes compared to those of human fetal brain, and the results of this new work suggest that the apparent increase of $\mathrm{Sm}$ seen with the fetal brain membranes radioreceptor assay is due to differences between adult and newborn $\mathrm{Sm}$ interaction with receptors rather than to a specific fetal form of Sm peptide (19).

In the human newborn, somatomedin levels are low when measured as sulfation bioactivity (20-23), radioreceptor activity $(1,24)$, and radioimmunoassay $(3,25-28)$. Moreover, preterm newborns have lower cord blood somatomedin values than fullterm newborns $(1,21,23,29)$. Both insulin-like growth factors IGF I and IGF II are positively correlated with gestational age (3).

Bioassayable growth-promoting activity measured as TA also is low in cord blood and increases after birth, as demonstrated in earlier reports from our laboratory $(10,11,30)$. TA is lower in cord blood of premature than of full-term newborns. Higher TA is found in blood obtained from neonatal vessels, either after clamping of the cord (7) or by capillary puncture immediately after birth (30), than in cord blood collected from the placental section. In term newborns whose birth weight was appropriate for gestational age, we found a serum TA of $1.50 \pm 0.7 \mathrm{U} / \mathrm{ml}$ and a level of radioimmunoassayable $\mathrm{Sm} \mathrm{C}$ of $0.52 \pm 0.03 \mathrm{U} /$ $\mathrm{ml}$. In these newborns, individual values of TA and $\mathrm{Sm} \mathrm{C}$ were positively correlated (7). Such a correlation was not studied in the present work, since the amount of serum available did not allow both measurements in the same fetuses.

The levels of $\mathrm{Sm} \mathrm{C}$ measured by radioimmunoassay in the human fetuses in the present study rose from nearly undetectable values $(0.05 \pm 0.06 \mathrm{U} / \mathrm{ml})$ at midpregnancy $(21-24 \mathrm{wk})$ to 0.24 $\pm 0.03 \mathrm{U} / \mathrm{ml}$ at $25-28 \mathrm{wk}$. This latter value is about half of the $0.52 \pm 0.03 \mathrm{U} / \mathrm{ml}$ level that we found in term newborns (7), in good agreement with the data of Bennett et al. (3) who measured IGF I and IGF II by radioimmunoassay in the cord blood of premature and term newborns and $\mathrm{Sm} \mathrm{C}$ by radioreceptor assay in term newborns. 
In sharp contrast, the serum TA decreased in the present study from $1.41 \pm 0.15 \mathrm{U} / \mathrm{ml}$ at midpregnancy to $0.95 \pm 0.06$ in 25 to 28 -wk fetuses (Fig. 1); this latter value was lower than the 1.50 $\pm 0.07 \mathrm{U} / \mathrm{ml}$ previously found in the blood of term newborns (7). These differences suggest that factors other than somatomedins contribute to the stimulating effect of human serum upon thymidine incorporation into lectin-activated lymphocytes and they vary during fetal life.

Measurements of serum transferrin were included in the present study since no values for living fetuses in utero have been reported. No change in transferrin levels was observed from the fetal age 21-24 to 25-28 wk. The overall mean fetal level that we found $(1.05 \pm 0.05 \mathrm{~g} /$ liter $)$ was significantly lower than that measured in our earlier study of term newborns $(1.68 \pm 0.14 \mathrm{~g}$ / liter) (7) and in another neonatal study (31).

In conclusion, this study of normal fetal blood confirms that the level of Sm C is very low at midpregnancy, a time where growth velocity is particularly high, and increases to term. On the other hand, the TA, high at midpregnancy, decreases. These data suggest that the humoral control of fetal growth may be related to mechanisms other than direct regulation by somatomedin.

\section{REFERENCES}

1. D'Ercole AJ, Foushee DB, Underwood LE 1976 Somatomedin-C receptor ontogeny and levels in porcine fetal and human cord serum. $J$ Clin Endocrinol Metab 43:1069-1077

2. D'Ercole AJ, Wilson DF, Underwood LE 1980 Changes in the circulating form of serum somatomedin-C during fetal life. J Clin Endocrinol Metab 51:674676

3. Bennett A, Wilson DH, Liu F, Nagashima R, Rosenfeld RG, Hintz RL 1983 levels of insulin-like growth factors I and II in human cord blood. J Clin Endocrinol Metab 57:609-612

4. Sara V, Hall K, Rodeck CH, Wetterberg L 1981 Human embryonic somatomedin. Proc Natl Acad Sci (USA) 78:3175-3179

5. Thiériot-Prévost G, Schimpff RM 1980 Mesure de l'incorporation de thymidine tritiée dans le lymphocyte activé et activité somatomédine du sérum. CR Acad Sci (Paris) 290:527-530

6. Thiériot-Prévost G, Schimpff RM 1981 A hormonally controlled serum factor stimulating the thymidine uptake into lectin-activated lymphocytes. Acta Endocrinol [Copenh] 98:358-363

7. Thiériot-Prévost G, Daffos F, Forestier F 1985 Serum somatomedin-C and bioassayable growth-promoting activity (thymidine activity) in appropriate and small-for-gestational age human newborns. Acta Endocrinol [Copenh] 110:32-35

8. Daffos F, Capella-Pavlovsky M, Forestier F 1983 A new procedure for fetal blood sampling in utero. Preliminary result of fifty-three cases. Am J Obstet Gynecol 146:985-987

9. Daffos F, Capella-Pavlovsky M, Forestier F 1983 Fetal blood sampling via the umbilical cord using a needle guided by ultrasound. Report of 66 cases. Prenatal Diag 3:271-277

10. Bozzola M, Schimpff RM, Ugazio A, Thiériot-Prévost G, Mingrat G, Nispoli L, Severi F, Job JC 1982 Age-related variation in growth promoting activity of human plasma measured in human lymphocytes. $J$ Clin Endocrinol Metab $55: 40-43$

11. Bozzola M, Schimpff RM, Mingrat G, Ghini M 1985 Serum growth-promoting activity measured as $3 \mathrm{H}$ thymidine incorporation into human activated lymphocytes and serum transferrin levels in newborns and mothers. Pediatr Res 19:220-223

12. Mancini G, Carbonara AO, Heremans JF 1965 Immunochemical quantitation of antigens by single medical immunodiffusion. Immunochemistry 2:235251

13. Daughaday WH, Parker KA, Barowski S, Trivedi B, Kapadia M 1982 Measurement of somatomedin-related peptides in fetal, neonatal and maternal rat serum by IGF I radioimmunoassay, IGF II radioreceptor assay (RRA) and multiplication-stimulating activity RRA after acid-ethanol extraction. Endocrinology 110:575-581

14. Grizzard JD, D'Ercole AJ, Wilkins JR, Moats-Starts BM, Williams RW 1984 Affinity-labeled somatomedin-C receptors and binding from the human fetus. J Clin Endocrinol Metab 58:535-543

15. Atkison PR, Weidman ER, Bhaumick B, Bala RM 1980 Release of somatomedin-like activity by cultured WI-38 human fibroblasts. Endocrinology 106:2006-2012

16. D'Ercole AJ, Wilson DF, Underwood LE 1980 Evidence that somatomedin is synthesized by multiple tissues in the fetus. Dev Biol 75:315-328

17. Clemmons DR, Van Wyk JJ 1985 Evidence for a functional role of endogenously produced somatomedin-like peptides in the regulation of DNA synthesis in cultured human fibroblasts and porcine smooth muscle cells. J Clin Invest 75:1914-1918

18. D'Ercole AJ, Stiles AD, Underwood LE 1984 Tissue concentrations of somatomedin-C: further evidence for multiple tissues synthesis and paracrine or autocrine mechanisms of action. Proc Natl Acad Sci (USA) 81:935-939

19. Thorsson AV, Hintz RL 1985 Interaction of human cord sera with somatomedin receptors of human fetal brain and placental membranes. 67th Annual Meeting of the Endocrine Society, Baltimore, June 19-21 1985, abstr 195, p 49

20. Tato L, Du Caju MVL, Prévôt C, Rappaport R 1975 Early variations of plasma somatomedin activity in the newborn. J Clin Endocrinol Metab 40:534-536

21. Gluckman PD, Brinsmead MW 1976 Somatomedin in cord blood: relationship to gestational age and birth size. J Clin Endocrinol Metab 43:1378-1381

22. Kastrup KW, Andersen HJ, Lebech P 1978 Somatomedin in newborns and the relationship to human chorionic somatotropin and fetal growth. Acta Paediatr Scand 67:757-762

23. Foley TP, De Philipp R, Perricelli A, Miller A 1980 Low somatomedin activity in cord serum from infants with intra-uterine growth retardation. J Pediatr 96:605-610

24. D'Ercole AJ, Underwood LE, Van Wyk JJ 1977 Serum somatomedin-C in hypopituitarism and in other disorders of growth. J Pediatr 90:375-381

25. Furlanetto RW, Underwood LE, Van Wyk JJ, D'Ercole AJ 1977 Estimation of somatomedin-C levels in normal and patients with pituitary disease by radioimmunoassay. J Clin Invest 60:648-657

26. Zapf J, Walter H, Froesch ER 1981 Radioimmunological determination of insulin-like growth factors $\mathrm{I}$ and II in normal subjects and in patients with growth disorders and extra-pancreatic tumor hypoglycemia. J Clin Invest 68:1321-1330

27. Kaplowitz PB, D'Ercole AJ, Van Wyk JJ, Underwood LE 1982 Plasma somatomedin-C during the first year of life. J Pediatr 100:932-934

28. Underwood LE, Clemmons DR, Van Wyk JJ, Chatelain PG, Copeland KC 1983 Plasma immunoreactive somatomedin-C/IGF I in the evaluation of short stature. In: Insulin-Like Growth Factors/Somatomedins. Walter de Gruyter and Co, New York, pp 235-254

29. Tato L, Dal Moro A, Piemonte G, Veigi V, Pizzo P, Volpato S, Gaburro D 1981 A longitudinal study on plasma somatomedin activity in full-term, preterm and small-for-gestational age newborns. Biol Neonate 39:160-164

30. Bozzola M, Schimpff RM 1984 Neonatal serum growth-promoting activity measured in human lymphocytes: comparison of cord and capillary blood. Horm Metab Res 17:418-420

31. Scott PH, Berger HM, Kenward C, Scott P, Wharton BA 1975 Effect of gestational age and intra-uterine nutrition on plasma transferrin and iron in the newborn. Arch Dis Child 50:796-798 